\title{
Evaluation of Ten Trace Elements in Riedel's Struma Using Neutron Activation Analysis
}

\author{
V Zaichick* \\ Radionuclide Diagnostics, Department Medical Radiological Research Centre, Obninsk, Russia
}

\begin{abstract}
Aims: Role of trace elements (TE) in etiology and pathogenesis of Riedel's disease (RD) is unclear. The aim of this exploratory study was to assess whether there were significant changes in thyroid tissue levels of ten TE ( $\mathrm{Ag}, \mathrm{Co}, \mathrm{Cr}, \mathrm{Fe}, \mathrm{Hg}, \mathrm{Rb}, \mathrm{Sb}, \mathrm{Sc}, \mathrm{Se}$, and $\mathrm{Zn}$ ) are present in the fibrotic transformed thyroid.
\end{abstract}

Methods: Ten TE of thyroid tissue were determined in 6 patients with RD and 105 healthy populations. The measurements were performed using non-destructive instrumental neutron activation analysis with high resolution spectrometry of long-lived radionuclides.

Results: Elevated mean values of Rb content were found in thyroid with RD in comparison with normal level.

Conclusions: There are considerable changes in Rb content in tissue of thyroid with RD. Thus, it is reasonable to assume that the level of Rb in thyroid tissue can be used as RD markers. However, this topic needs additional studies.

Keywords: Riedel's disease, Thyroid, Trace elements, Neutron activation analysis

Running head: Ten trace element contents in Riedel's struma

\section{Introduction}

Riedel's struma, also called Riedel's disease and Riedel's thyroiditis. is a peculiarly hard, infiltrative lesion (nodule) of the thyroid gland. ${ }^{1}$ Riedel's disease (RD) is a rare form of chronic thyroiditis of unknown etiology associated with global or partial fibrosis of the thyroid gland, destruction of the thyroid follicle architecture, obliterative phlebitis, and a mixed infiltrate of lymphocytes, eosinophils, and plasma cells. ${ }^{1,2}$ Clinical differentiation between RD, Hashimoto's disease, and other thyroid benign and malignant nodules is often difficult. ${ }^{2,3}$ We hypothesized that disbalance of trace elements (TE) contents in thyroid tissue may play a significant role in etiology and pathogenesis of RD. Furthermore, specific levels of TE contents in fibrotic transformed thyroid tissue may be used as
RD biomarkers. For over $20^{\text {th }}$ century, there was the dominant opinion that all thyroid nodules (TN), including RD, are the elementary consequence of iodine (I) deficiency. However, TN have been found to be a frequent disease even in those countries and regions where the population is never exposed to I deficiency. ${ }^{4}$ Moreover, it was shown that iodine excess has severe effects on human health and associated with the development of thyroidal disfunctions and autoimmunity, nodular and diffuse goiter, benign and malignant tumors of gland..$^{5-8}$ It was also demonstrated that besides the iodine deficiency and excess many other dietary, environmental, and occupational factors are associated with the TN incidence. ${ }^{9-11}$ Among them a disturbance of evolutionary stable input of many chemical elements in human body after industrial revolution plays a significant role in etiology of thyroidal disorders. ${ }^{12}$

\begin{tabular}{|l|l|}
\hline \hline Quick Response Code: & *Corresponding author: Vladimir Zaichick, Medical Radiological Research Centre, Korolyev \\
St.4, Obninsk 249036, Kaluga Region, Russia \\
Received: 10 October, $2021 \quad$ Published: 17 November, 2021 \\
Citation: Zaichick V. Evaluation of Ten Trace Elements in Riedel's Struma Using Neutron Acti- \\
vation Analysis. Mod Res Clin Canc Prev. 2021;1(1):1-6. DOI: \\
10.53902/MRCCP.2021.01.000502
\end{tabular}


In addition to I, many other TE are involved in essential physiological functions. ${ }^{13}$ Essential or toxic (goitrogenic, mutagenic, carcinogenic) properties of TE depend on tissue-specific need or tolerance, respectively. ${ }^{13}$ Deficiency, overload or an imbalance of the TE may result in cellular dysfunction, degeneration, death, benign or malignant transformation. ${ }^{13-15}$ In our previous studies the complex of in vivo and in vitro nuclear analytical and related methods was developed and employed for the investigation of I and other TE levels in the normal and pathological thyroid gland. ${ }^{16-22}$ Level of I in the normal gland was studied in relation to age, gender and some non-thyroidal diseases..$^{23,24}$ After that, variations of many other TE content with age in the thyroid of males and females were investigated and age- and gender-dependence of some TE was observed ${ }^{25-41}$ Furthermore, a significant difference between some TE mass fractions in normal and malignant thyroid was demonstrated. ${ }^{42-47}$ So far, the etiology and pathogenesis of RD has to be considered as multifactorial. The present study was performed to clarify the role of some TE in the RD etiology. With this in mind, our aim was to assess the silver (Ag), cobalt ( $\mathrm{Co})$, chromium ( $\mathrm{Cr}$ ), iron ( $\mathrm{Fe})$, mercury (Hg), rubidium (Rb), antimony (Sb), scandium (Sc), selenium (Se), and zinc (Zn) contents in normal thyroid tissue (NT) and $\mathrm{RD}$ tissue using non-destructive instrumental neutron activation analysis with high resolution spectrometry of long-lived radionuclides (INAA-LLR). A further aim was to compare the levels of these TE in the NT and RD groups of samples.

\section{Material and Methods}

All patients with RD ( $\mathrm{n}=6,5$ females and 1 male, mean age $\mathrm{M} \pm \mathrm{SD}$ was $39 \pm 9$ years, range $34-50$ ) were hospitalized in the Head and Neck Department of the MRRC. Thick-needle puncture biopsy of suspicious lesion of the gland was performed for every persons, to allow morphological examination of affected thyroid tissue and to determine their TE contents. For all patients the diagnosis has been confirmed by clinical and morphological results obtained during studies of biopsy and resected materials. Histological conclusion for all thyroidal lesions was the RD. Normal thyroid samples were removed at necropsy from 105 deceased (mean age $44 \pm 21$ years, range 2-87), who had died suddenly. The majority of deaths were due to trauma. Histological examination was used in the NT group to match the age criteria, as well as to confirm the absence of micro-nodules and underlying cancer. All studies were approved by the Ethical Committees of the Medical Radiological Research Centre (MRRC), Obninsk. All the procedures performed in studies involving human participants were in accordance with the ethical standards of the institutional and/or national research committee and with the 1964 Helsinki declaration and its later amendments, or with comparable ethical standards. All thyroid samples were divided into two parts using a titanium scalpel..$^{48}$ One was used for morphological study while the other was for TE evaluation. All samples for TE analysis were weighed, freeze-dried and homogenized. ${ }^{49}$ The pounded sample weighing about 5-10mg (for biopsy) and 50mg (for resected materials) was used for trace element measurement by INAA-LLR.

Details of sample preparation, activation by neutrons of nuclear reactor, gamma-spectrometry, calibration with biological synthetic standards, and quality insurance using certified reference material (CRM) of International Atomic Energy Agency (IAEA) CRM IAEA $\mathrm{H}-4$ (animal muscle) were presented in our earlier publications concerning the INAA-LLR of TE contents in human thyroid, prostate and hair. ${ }^{18,29,30,50-52} \mathrm{~A}$ dedicated computer program for INAA-LLR mode optimization was used..$^{53}$ All the thyroid samples were prepared in duplicate, and mean values of TE contents were used in the final calculation. Using Microsoft Office Excel, a summary of the statistics, including arithmetic mean, standard deviation, standard error of the mean, minimum and maximum values, median, percentiles with 0.025 and 0.975 levels was calculated for TE contents in NT and RD groups of tissue samples. The difference in the results between two groups (NT and RD) was evaluated by the parametric Student's t-test and non-parametric Wilcoxon-Mann-Whitney U-test.

\section{Results}

Table 1 presents certain statistical parameters of the $\mathrm{Ag}$, Co, $\mathrm{Cr}$, $\mathrm{Fe}, \mathrm{Hg}, \mathrm{Rb}, \mathrm{Sb}, \mathrm{Sc}, \mathrm{Se}$, and $\mathrm{Zn}$ mass fraction in normal thyroid and Riedel's struma. Comparison of values obtained for Ag, Co, Cr, Fe, $\mathrm{Hg}, \mathrm{Rb}, \mathrm{Sb}, \mathrm{Sc}$, Se, and Zn contents in the NT samples with median of means reported by other researches ${ }^{54-66}$ depicts in Table 2. The ratios of means and the difference between mean values of $\mathrm{Ag}$, Co, $\mathrm{Cr}, \mathrm{Fe}, \mathrm{Hg}, \mathrm{Rb}, \mathrm{Sb}, \mathrm{Sc}$, Se, and $\mathrm{Zn}$ mass fractions in normal thyroid and Riedel's struma are presented in Table 3.

\section{Discussion}

As was shown before ${ }^{18,29,30,50-52}$ good agreement of the Ag, Co, Cr, $\mathrm{Fe}, \mathrm{Hg}, \mathrm{Rb}, \mathrm{Sb}, \mathrm{Sc}$, Se, and $\mathrm{Zn}$ contents analyzed by INAA-LLR with the certified data of CRM IAEA H-4 indicates acceptable accuracy of the results obtained in the study of TE of the thyroid samples presented in Tables 1-3. The mean values and all selected statistical parameters were calculated for all ten TE (Ag, Co, Cr, Fe, Hg, Rb, Sb, Sc, Se, and Zn) mass fractions in NT and RD groups of tissue samples (Table 1). In a general sense values obtained for $\mathrm{Cr}, \mathrm{Fe}, \mathrm{Hg}, \mathrm{Rb}$, $\mathrm{Sb}, \mathrm{Sc}, \mathrm{Se}$, and Zn contents in the NT samples (Table 2) agree well with median of mean values reported by other researches. ${ }^{54-66}$ The obtained means for Ag and Co were almost one order of magnitude lower median of previously reported means but inside the range of means (Table 2). A number of values for TE mass fractions were not expressed on a dry mass basis by the authors of the cited references. However, we calculated these values using published data for water $(75 \%)^{67}$ and ash $\left(4.16 \%\right.$ on dry mass basis) ${ }^{68}$ contents in 
thyroid of adults. Data cited in Table 2 for NT also includes samples obtained from patients who died from different non-endocrine diseases. In our previous study it was shown that some non-endocrine diseases can effect on TE contents in thyroid. ${ }^{24}$ Moreover, in many studies the "normal" thyroid means a visually non-affected tissue adjacent to benign or malignant thyroidal nodules. However, there are no data on a comparison between the TE contents in such kind of samples and those in thyroid of healthy persons, which permits to confirm their identity. The data on TE levels in RD tissue were not found in the literature.

Table 1: Some statistical parameters of Ag, Co, Cr, Fe, Hg, Rb, Sb, Sc, Se, and Zn mass fraction (mg/kg, dry mass basis) in normal thyroid and Riedel's struma.

\begin{tabular}{|l|l|c|c|c|c|c|c|c|c|}
\hline Tissue & Element & Mean & SD & SEM & Min & Max & Median & P 0.025 & P 0.975 \\
\hline Normal & Ag & 0.0151 & 0.0140 & 0.0016 & 0.0012 & 0.0800 & 0.0121 & 0.0017 & 0.0454 \\
\hline thyroid & Co & 0.0399 & 0.0271 & 0.0030 & 0.0046 & 0.140 & 0.0327 & 0.0134 & 0.124 \\
\hline $\mathrm{n}=105$ & $\mathrm{Cr}$ & 0.539 & 0.272 & 0.032 & 0.130 & 1.30 & 0.477 & 0.158 & 1.08 \\
\hline & $\mathrm{Fe}$ & 225 & 100 & 11 & 51.0 & 512 & 217 & 67.4 & 456 \\
\hline & $\mathrm{Hg}$ & 0.0421 & 0.0358 & 0.0041 & 0.0065 & 0.180 & 0.0304 & 0.0091 & 0.150 \\
\hline & $\mathrm{Rb}$ & 7.37 & 4.10 & 0.44 & 1.11 & 29.4 & 6.49 & 2.60 & 16.7 \\
\hline & $\mathrm{Sb}$ & 0.111 & 0.072 & 0.008 & 0.0047 & 0.308 & 0.103 & 0.0117 & 0.280 \\
\hline & $\mathrm{Sc}$ & 0.0046 & 0.0038 & 0.0008 & 0.0002 & 0.0143 & 0.0042 & 0.00035 & 0.0131 \\
\hline & $\mathrm{Se}$ & 2.32 & 1.29 & 0.14 & 0.439 & 5.80 & 2.01 & 0.775 & 5.65 \\
\hline & $\mathrm{Zn}$ & 97.8 & 42.3 & 4.5 & 8.10 & 221 & 91.7 & 34.8 & 186 \\
\hline Riedel's & $\mathrm{Ag}$ & 0.225 & 0.123 & 0.087 & 0.138 & 0.312 & 0.225 & 0.142 & 0.308 \\
\hline struma & $\mathrm{Co}$ & 0.0588 & 0.0157 & 0.0111 & 0.0477 & 0.0699 & 0.0588 & 0.0483 & 0.0693 \\
\hline $\mathrm{n}=6$ & $\mathrm{Cr}$ & 1.14 & 1.05 & 0.74 & 0.396 & 1.88 & 1.14 & 0.433 & 1.84 \\
\hline & $\mathrm{Fe}$ & 382 & 295 & 148 & 123 & 797 & 304 & 131 & 765 \\
\hline & $\mathrm{Hg}$ & 0.529 & 0.088 & 0.063 & 0.466 & 0.591 & 0.529 & 0.469 & 0.588 \\
\hline & $\mathrm{Rb}$ & 15.3 & 4.4 & 2.2 & 9.70 & 20.3 & 15.6 & 10.1 & 20.0 \\
\hline & $\mathrm{Sb}$ & 0.0990 & 0.0198 & 0.0140 & 0.0850 & 0.113 & 0.0990 & 0.0857 & 0.112 \\
\hline & $\mathrm{Sc}$ & 0.0150 & 0.0207 & 0.0150 & 0.00030 & 0.0296 & 0.0150 & 0.00103 & 0.0289 \\
\hline & $\mathrm{Se}$ & 2.11 & 0.33 & 0.23 & 1.88 & 2.34 & 2.11 & 1.89 & 2.33 \\
\hline & $\mathrm{Zn}$ & 79.5 & 32.1 & 16.0 & 58.0 & 127 & 66.5 & 58.4 & 123 \\
\hline
\end{tabular}

M: Arithmetic mean; SD: Standard Deviation; SEM: Standard Error of Mean; Min: Minimum Value; Max: Maximum Value; P 0.025: Percentile with 0.025 Level; P 0.975: Percentile with 0.975 Level

Table 2: Median, minimum and maximum value of means $\mathrm{Ag}$, $\mathrm{Co}, \mathrm{Cr}, \mathrm{Fe}, \mathrm{Hg}, \mathrm{Rb}, \mathrm{Sb}, \mathrm{Sc}, \mathrm{Se}$, and $\mathrm{Zn}$ contents in normal thyroid according to data from the literature in comparison with our results $(\mathrm{mg} / \mathrm{kg}$, dry mass basis).

\begin{tabular}{|c|c|c|c|c|c|}
\hline \multirow{2}{*}{ Tissue } & \multirow{2}{*}{ El } & \multicolumn{3}{|c|}{ Published data [Reference] } & \multirow{2}{*}{$\begin{array}{c}\text { This work } \\
\mathrm{M} \pm \mathrm{SD}\end{array}$} \\
\hline & & $\begin{array}{l}\text { Median of } \\
\text { means (n)* }\end{array}$ & $\begin{array}{l}\text { Minimum of means } \\
M \text { or } M \pm S D,(n)^{* *}\end{array}$ & $\begin{array}{l}\text { Maximum of means } \\
\text { M or } M \pm S D,(n)^{* *}\end{array}$ & \\
\hline \multirow[t]{10}{*}{ Normal } & $\mathrm{Ag}$ & $0.21(12)$ & $0.000784(16)^{54}$ & $1.20 \pm 1.24(105)^{55}$ & $0.015 \pm 0.014$ \\
\hline & Co & $0.306(25)$ & $0.016(66)^{56}$ & $70.4 \pm 40.8(14)^{57}$ & $0.040 \pm 0.027$ \\
\hline & $\mathrm{Cr}$ & $0.69(17)$ & $0.088(83)^{58}$ & $24.8 \pm 2.4(4)^{59}$ & $0.54 \pm 0.27$ \\
\hline & $\mathrm{Fe}$ & $252(21)$ & $56(120)^{60}$ & $3360(25)^{61}$ & $225 \pm 100$ \\
\hline & $\mathrm{Hg}$ & $0.08(13)$ & $0.0008 \pm 0.0002(10)^{62}$ & $396 \pm 40(4)^{59}$ & $0.042 \pm 0.036$ \\
\hline & $\mathrm{Rb}$ & $7.8(9)$ & $\leq 0.85(29)^{62}$ & $294 \pm 191(14)^{57}$ & $7.37 \pm 4.10$ \\
\hline & $\mathrm{Sb}$ & $0.15(10)$ & $0.040 \pm 0.003(-)^{63}$ & $\leq 12.4(-)^{64}$ & $0.111 \pm 0.072$ \\
\hline & Sc & $0.009(4)$ & $0.0018 \pm 0.0003(17)^{56}$ & $0.014 \pm 0.005(10)^{62}$ & $0.005 \pm 0.004$ \\
\hline & $\mathrm{Se}$ & $2.32(21)$ & $0.436(40)^{65}$ & $756 \pm 680(14)^{57}$ & $2.32 \pm 1.29$ \\
\hline & $\mathrm{Zn}$ & $110(56)$ & $2.1(-)^{66}$ & $820 \pm 204(14)^{57}$ & $97.8 \pm 42.3$ \\
\hline
\end{tabular}

El: Element; M: Arithmetic Mean; SD: Standard Deviation; (n)*: Number of all References; (n)**: Number of Samples

The range of means of $\mathrm{Ag}$, Co, $\mathrm{Cr}, \mathrm{Fe}, \mathrm{Hg}, \mathrm{Rb}, \mathrm{Sb}, \mathrm{Sc}, \mathrm{Se}$, and $\mathrm{Zn}$ level reported in the literature for NT tissue vary widely (Table 2). This can be explained by a dependence of TE content on many factors, including "normality" of thyroid samples (see above), the region of the thyroid, from which the sample was taken, age, gender, ethnicity, mass of the gland, and its functional activity. Not all these factors were strictly controlled in cited studies. However, in our opinion, the main reason for the inter-observer discrepancy can be attributed to the accuracy of the analytical techniques, sample preparation methods, and the inability to take standardized samples from affected tissues. It was insufficient quality control of results in these studies. In many scientific reports, tissue samples 
were ashed or dried at high temperature for many hours. In other cases, thyroid samples were treated with solvents (distilled water, ethanol, formalin etc). There is evidence that during ashing, drying and digestion at high temperature some quantities of certain TE are lost as a result of this treatment. That concerns not only such volatile halogen as $\mathrm{Br}$, but also other TE investigated in the study. ${ }^{69,70}$

From Table 3, it is observed that in RD samples the mass fraction of $\mathrm{Rb}$ is approximately 2.1 times higher than in NT. Thus, if we accept the TE contents in the NT group as a norm, we have to conclude that with a fibrotic transformation the $\mathrm{Rb}$ level in thyroid tissue significantly changed. Characteristically, elevated or reduced levels of TE observed in affected tissues are discussed in terms of their potential role in the initiation and promotion of TN. In other words, using the low or high levels of the TE in TN researchers try to determine the role of the deficiency or excess of each TE in the TN etiology. In our opinion, abnormal levels of many TE in TN, including RD, could be and cause, and also effect of thyroid tissue transformation. From the results of such kind studies, it is not always possible to decide whether the measured decrease or increase in TE level in pathologically altered tissue is the reason for alterations or vice versa. Nevertheless the differences between TE levels in normal and affected thyroid tissue could be used as RD markers. This study has several limitations. Firstly, analytical techniques employed in this study measure only ten TE (Ag, Co, $\mathrm{Cr}, \mathrm{Fe}$, $\mathrm{Hg}, \mathrm{Rb}, \mathrm{Sb}, \mathrm{Sc}, \mathrm{Se}$, and $\mathrm{Zn}$ ) mass fractions. Future studies should be directed toward using other analytical methods which will extend the list of TE investigated in NT and RD. Secondly, the sample size of RD group was relatively small and prevented investigations of TE contents in RD group using differentials like gender, thyroid functional activity, stage of disease, dietary habits of healthy persons and patients with RD. Lastly, generalization of our results may be limited to Russian population. Despite these limitations, this study provides evidence on fibrotic-specific tissue Rb level alteration and shows the necessity to continue TE research of RD.

Table 3: Differences between mean values (M $\pm \mathrm{SEM}$ ) of $\mathrm{Ag}$, $\mathrm{Co}, \mathrm{Cr}, \mathrm{Fe}, \mathrm{Hg}, \mathrm{Rb}, \mathrm{Sb}$, Sc, Se, and $\mathrm{Zn}$ mass fraction (mg/kg, dry mass basis) in normal thyroid and Riedel's struma.

\begin{tabular}{|l|c|c|c|c|c|}
\hline \multirow{2}{*}{ Element } & \multicolumn{4}{|c|}{ Thyroid tissue } & Ratio \\
\cline { 2 - 6 } & $\begin{array}{c}\text { Normal thyroid } \\
\mathbf{n = 1 0 5}\end{array}$ & $\begin{array}{c}\text { Riedel's struma } \\
\mathbf{n = 6}\end{array}$ & $\begin{array}{c}\text { Student's t-test } \\
\mathbf{p} \leq\end{array}$ & $\begin{array}{c}\text { U-test } \\
\mathbf{p}\end{array}$ & $\begin{array}{c}\text { Riedel's struma to } \\
\text { normal thyroid }\end{array}$ \\
\hline $\mathrm{Ag}$ & $0.0151 \pm 0.0016$ & $0.225 \pm 0.087$ & 0.250 & $>0.05$ & 14.9 \\
\hline $\mathrm{Co}$ & $0.0399 \pm 0.0030$ & $0.0588 \pm 0.0111$ & 0.322 & $>0.05$ & 1.47 \\
\hline $\mathrm{Cr}$ & $0.539 \pm 0.032$ & $1.14 \pm 0.74$ & 0.567 & $>0.05$ & 2.12 \\
\hline $\mathrm{Fe}$ & $225 \pm 11$ & $382 \pm 148$ & 0.366 & $>0.05$ & 1.70 \\
\hline $\mathrm{Hg}$ & $0.0421 \pm 0.0041$ & $0.529 \pm 0.063$ & 0.080 & $>0.05$ & 12.6 \\
\hline $\mathrm{Rb}$ & $7.37 \pm 0.44$ & $15.3 \pm 2.2$ & $\mathbf{0 . 0 3 3}$ & $\leq \mathbf{0 . 0 1}$ & 2.08 \\
\hline $\mathrm{Sb}$ & $0.111 \pm 0.008$ & $0.0990 \pm 0.0140$ & 0.554 & $>0.05$ & 0.89 \\
\hline $\mathrm{Sc}$ & $0.0046 \pm 0.0008$ & $0.0150 \pm 0.0150$ & 0.607 & $>0.05$ & 3.26 \\
\hline $\mathrm{Se}$ & $2.32 \pm 0.14$ & $2.11 \pm 0.23$ & 0.531 & $>0.05$ & 0.91 \\
\hline $\mathrm{Zn}$ & $97.8 \pm 4.5$ & $79.5 \pm 16.0$ & 0.340 & $>0.05$ & 0.81 \\
\hline
\end{tabular}

M: Arithmetic Mean; SEM: Standard Error of Mean; Sstatistically significant values are in bold.

\section{Conclusion}

In this work, TE measurements in tissue samples from NT and RD were performed using INAA-LLR. It was shown that INAA-LLR is an adequate analytical tool for the non-destructive determination of $\mathrm{Ag}, \mathrm{Co}, \mathrm{Cr}, \mathrm{Fe}, \mathrm{Hg}, \mathrm{Rb}, \mathrm{Sb}, \mathrm{Sc}, \mathrm{Se}$, and $\mathrm{Zn}$ content in tissue samples from healthy and affected human thyroid, including needle biopsy samples. It was observed that in RD contents of $\mathrm{Rb}$ were significantly higher than in normal tissues. In our opinion, the increase in levels of $\mathrm{Rb}$ in thyroid with RD might demonstrate an involvement of this TE in etiology and pathogenesis of RD. It was assumed that the difference in Br level in affected thyroid tissue could be used as RD marker.

\section{Acknowledgements}

The author is extremely grateful to Profs. B.M. Vtyurin and V.S.
Medvedev, Medical Radiological Research Center, Obninsk, as well as to Dr. Yu. Choporov, former Head of the Forensic Medicine Department of City Hospital, Obninsk, for supplying thyroid samples.

\section{Funding}

There were no any sources of funding that have supported this work.

\section{Conflicts of Interest}

Author declares that there is no conflict of interest.

\section{References}

1. Dahlgren M, Khosroshahi A, Petur Nielsen G, et al. Riedel's thyroiditis and multifocal fibrosclerosis are part of the IgG4-related systemic disease spectrum. Arthritis Care Res (Hoboken). 2010;62(9):1312-1318.

2. Junik R, Juraniec 0, Pypkowski J, et al. A difficult diagnosis: a case report of combined Riedel's disease and fibrosing Hashimoto's thyroid- 


\section{itis. Endokrynol Pol. 2011;62(4):351-356.}

3. Heufelder AE, Hay ID. Evidence for autoimmune mechanisms in the evolution of invasive fibrous thyroiditis (Riedel's struma). Clin Investig. 1994;72(10):788-793.

4. Derwahl M, Studer H. Multinodular goitre: 'much more to it than simply iodine deficiency'. Baillieres Best Pract Res Clin Endocrinol Metab. 2000;14(4):577-600.

5. Zaichick V. Iodine excess and thyroid cancer. J Trace Elem Exp Med. 1998;1(4):508-509.

6. Zaichick V, Iljina T. Dietary iodine supplementation effect on the rat thyroid 131I blastomogenic action. In: Die Bedentung der Mengenund Spurenelemente. 18. Arbeitstangung. Friedrich-Schiller-Universität, Jena. 1998; pp. 294-306.

7. Kim S, Kwon YS, Kim JY, et al. Association between Iodine Nutrition Status and Thyroid Disease-Related Hormone in Korean Adults: Korean National Health and Nutrition Examination Survey VI (2013-2015). Nutrients. 2019;11(11):2757.

8. Vargas-Uricoechea P, Pinzón-Fernández MV, Bastidas-Sánchez BE, et al. Iodine status in the colombian population and the impact of universal salt iodization: a double-edged sword?. J Nutr Metab. 2019: 6239243.

9. Stojsavljević A, Rovčanin B, Krstić D, et al. Risk assessment of toxic and essential trace metals on the thyroid health at the tissue level: The significance of lead and selenium for colloid goiter disease. Expo Health. 2019.

10. Fahim YA, Sharaf NE, Hasani IW, et al. Assessment of thyroid function and oxidative stress state in foundry workers exposed to lead. J Health Pollut. 2000;10(27):200903.

11. Liu M, Song J, Jiang Y, et al.) A case-control study on the association of mineral elements exposure and thyroid tumor and goiter. Ecotoxicol Environ Saf. 2021;208:111615.

12. Zaichick V. Medical elementology as a new scientific discipline. $J R a$ dioanal Nucl Chem. 2006; 269:303-309.

13. Moncayo R, Moncayo H. A post-publication analysis of the idealized upper reference value of $2.5 \mathrm{mIU} / \mathrm{L}$ for TSH: Time to support the thyroid axis with magnesium and iron especially in the setting of reproduction medicine. BBA Clin. 2017;7:115-119.

14. Beyersmann D, Hartwig A. Carcinogenic metal compounds: recent insight into molecular and cellular mechanisms. Arch Toxicol. 2018;82(8):493-512.

15. Martinez-Zamudio R, Ha HC. Environmental epigenetics in metal exposure. Epigenetics. 2011;6(7):820-827.

16. Zaĭchik VE, Raibukhin Yu S, Melnik AD, et al. Neutron-activation analysis in the study of the behavior of iodine in the organism. Med Radiol (Mosk). 1970;15(1):33-36.

17. Zaĭchik VE, Matveenko EG, Vtiurin BM, Intrathyroid iodine in the diagnosis of thyroid cancer. Vopr Onkol. 1982;28(3):18-24.

18. Zaichick V, Tsyb AF, Vtyurin BM. Trace elements and thyroid cancer. Analyst. 1995;120(3):817-821.

19. Zaichick VYe, Choporov YuYa. Determination of the natural level of human intra-thyroid iodine by instrumental neutron activation analysis. J Radioanal Nucl Chem. 1996;207(1):153-161.

20. Zaichick V. In vivo and in vitro application of energy-dispersive XRF in clinical investigations: experience and the future. J Trace Elem Exp Med. 1998;11(4):509-510.

21. Zaichick V, Zaichick S. Energy-dispersive X-ray fluorescence of iodine in thyroid puncture biopsy specimens. J Trace Microprobe Tech. 1999;17(2):219-232.
22. Zaichick V. Relevance of, and potentiality for in vivo intrathyroidal iodine determination. Ann N Y Acad Sci. 2000;904:630-632.

23. Zaichick V, Zaichick S. Normal human intrathyroidal iodine. Sci Total Environ. 1997;206(1):39-56.

24. Zaichick V. Human intrathyroidal iodine in health and non-thyroidal disease. In: New aspects of trace element research. Eds: M Abdulla, M Bost, S Gamon, P Arnaud, G Chazot. Smith-Gordon, London, and Nishimura, Tokyo. 1999. Pp.114-119.

25. Zaichick V, Zaichick S. Age-related changes of some trace element contents in intact thyroid of females investigated by energy dispersive X-ray fluorescent analysis. Trends Geriatr Healthc. 2017;1(1):31-38.

26. Zaichick V, Zaichick S. Age-related changes of some trace element contents in intact thyroid of males investigated by energy dispersive X-ray fluorescent analysis. MOJ Gerontol Ger. 2017;1(5):00028.

27. Zaichick V, Zaichick S. Age-related changes of $\mathrm{Br}, \mathrm{Ca}, \mathrm{Cl}, \mathrm{I}, \mathrm{K}, \mathrm{Mg}, \mathrm{Mn}$, and $\mathrm{Na}$ contents in intact thyroid of females investigated by neutron activation analysis. Curr Updates Aging. 2017;1:5.1.

28. Zaichick V, Zaichick S. Age-related changes of $\mathrm{Br}, \mathrm{Ca}, \mathrm{Cl}, \mathrm{I}, \mathrm{K}, \mathrm{Mg}, \mathrm{Mn}$, and $\mathrm{Na}$ contents in intact thyroid of males investigated by neutron activation analysis. J Aging Age Relat Dis. 2017;1(1):1002.

29. Zaichick V, Zaichick S. Age-related changes of Ag, Co, Cr, Fe, Hg, Rb, $\mathrm{Sb}, \mathrm{Sc}, \mathrm{Se}$, and $\mathrm{Zn}$ contents in intact thyroid of females investigated by neutron activation analysis. J Gerontol Geriatr Med. 2017;3:015.

30. Zaichick V, Zaichick S. Age-related changes of Ag, Co, Cr, Fe, Hg, Rb, $\mathrm{Sb}, \mathrm{Sc}, \mathrm{Se}$, and $\mathrm{Zn}$ contents in intact thyroid of males investigated by neutron activation analysis. Curr Trends Biomedical Eng Biosci. 2017;4(4):555644.

31. Zaichick V, Zaichick S. Effect of age on chemical element contents in female thyroid investigated by some nuclear analytical methods. Micro Medicine. 2018;6(1):47-61.

32. Zaichick $V$, Zaichick $S$. Neutron activation and X-ray fluorescent analysis in study of association between age and chemical element contents in thyroid of males. Op Acc J Bio Eng Bio Sci. 2018;2(4):202-212.

33. Zaichick V, Zaichick S. Variation with age of chemical element contents in females' thyroids investigated by neutron activation analysis and inductively coupled plasma atomic emission spectrometry. J Biochem Analyt Stud. 2018;3(1):1-10.

34. Zaichick V, Zaichick S. Association between age and twenty chemical element contents in intact thyroid of males. SM Gerontol Geriatr Res. 2018;2(1):1014.

35. Zaichick V, Zaichick S. Associations between age and 50 trace element contents and relationships in intact thyroid of males. Aging Clin Exp Res. 2018;30(9):1059-1070.

36. Zaichick V, Zaichick S. Possible role of inadequate quantities of intra-thyroidal bromine, rubidium and zinc in the etiology of female subclinical hypothyroidism. EC Gynaecology. 2018;7(3):107-115.

37. Zaichick V, Zaichick S. Possible role of inadequate quantities of intra-thyroidal bromine, calcium and magnesium in the etiology of female subclinical hypothyroidism. Int Gyn and Women's Health. 2018;1(3).

38. Zaichick V, Zaichick S. Possible role of inadequate quantities of intra-thyroidal cobalt, rubidium and zinc in the etiology of female subclinical hypothyroidism. Womens Health Sci J. 2018;2(1):000108.

39. Zaichick V, Zaichick S. Association between female subclinical hypothyroidism and inadequate quantities of some intra-thyroidal chemical elements investigated by X-ray fluorescence and neutron activation analysis. Gynaecology and Perinatology. 2018;2(4):340-355.

40. Zaichick V, Zaichick S. Investigation of association between the high risk of female subclinical hypothyroidism and inadequate quantities 
of twenty intra-thyroidal chemical elements. Clin Res: Gynecol Obstet. 2018;1(1):1-18.

41. Zaichick V, Zaichick S. Investigation of association between the high risk of female subclinical hypothyroidism and inadequate quantities of intra-thyroidal trace elements using neutron activation and inductively coupled plasma mass spectrometry. Acta Scientific Medical Sciences. 2018;2(9):23-37.

42. Zaichick V. Zaichick S. Trace element contents in thyroid cancer investigated by energy dispersive X-ray fluorescent analysis. American Journal of Cancer Research and Reviews. 2018;2:5.

43. Zaichick V, Zaichick S. Trace element contents in thyroid cancer investigated by instrumental neutron activation analysis. J Oncol Res. 2018;2(1):1-13.

44. Zaichick V, Zaichick S. Variation in selected chemical element contents associated with malignant tumors of human thyroid gland. Cancer Studies. 2018;2(1):2.

45. Zaichick V, Zaichick S. Twenty chemical element contents in normal and cancerous thyroid. Int J Hematol Blo Dis. 2018;3(2):1-13.

46. Zaichick V, Zaichick S. Levels of chemical element contents in thyroid as potential biomarkers for cancer diagnosis (a preliminary study). $J$ Cancer Metastasis Treat. 2018;4:60.

47. Zaichick V, Zaichick S. Fifty trace element contents in normal and cancerous thyroid. Acta Scientific Cancer Biology. 2018;2(8):21-38.

48. Zaichick V, Zaichick S. Instrumental effect on the contamination of biomedical samples in the course of sampling. The Journal of Analytical Chemistry. 2018;51(12):1200-1205.

49. Zaichick V, Zaichick S. A search for losses of chemical elements during freeze-drying of biological materials. J Radioanal Nucl Chem. 2018;218(2):249-253.

50. Zaichick V. Applications of synthetic reference materials in the medical Radiological Research Centre. Fresenius J Anal Chem. 1995;352:219223.

51. Zaichick S, Zaichick V. The effect of age on $\mathrm{Ag}, \mathrm{Co}, \mathrm{Cr}, \mathrm{Fe}, \mathrm{Hg}, \mathrm{Sb}, \mathrm{Sc}$, $\mathrm{Se}$, and $\mathrm{Zn}$ contents in intact human prostate investigated by neutron activation analysis. J Appl Radiat Isot. 2011;69:827-833.

52. Zaichick S, Zaichick V. The effect of age and gender on 37 chemical element contents in scalp hair of healthy humans. Biol Trace Elem Res. 2010;134(1):41-54

53. Korelo AM, Zaichick V. Software to optimize the multielement INAA of medical and environmental samples. In: Activation Analysis in Environment Protection. Joint Institute for Nuclear Research, Dubna, Russia. 1993: pp.326-332.

54. Zhu H, Wang N, Zhang Y, et al. Element contents in organs and tissues of Chinese adult men. Health Phys. 2010;98(1):61-73.

55. Vlasova ZA. Trace element dynamics in thyroid in connection with age and atherosclerosis. Proceedings of Leningradskii Institute of Medical Doctor Postgraduate Education. 1969;80:135-144.
56. Stojsavljević A, Rovčanin B, Krstić D, et al. Risk assessment of toxic and essential trace metals on the thyroid health at the tissue level: The significance of lead and selenium for colloid goiter disease. Expo Health. 2019.

57. Salimi J, Moosavi K, Vatankhah S, etal. Investigation of heavy trace elements in neoplastic and non-neoplastic human thyroid tissue: A study by proton - induced X-ray emissions. Iran J Radiat Res. 2004;1(4):211216.

58. Reitblat MA, Kropachyev AM. Some trace elements in thyroid of the Perm Pricam'ya residents. Proceedings of Perm Medical Institute. 1967;78:157-164

59. Reddy SB, Charles MJ, Kumar MR, et al. Trace elemental analysis of adenoma and carcinoma thyroid by PIXE method. Nuclear Instruments and Methods in Physics Research Section B: Beam Interactions with Materials and Atoms. 2002;196(3-4):333-339.

60. Ataullachanov IA. Age changes in the content of manganese, cobalt, copper, zinc and iron in the endocrine glands of women. Probl Endocrinol (Mosk). 1969;15(2):98-102.

61. Kamenev VF. About trace element contents in thyroid of adults. In: Trace Elements in Agriculture and Medicine. Buryatia publishing-house, Ulan-Ude, Russia, 1963. Pp.12-16.

62. Boulyga SF, Zhuk IV, Lomonosova EM, et al. Determination of microelements in thyroids of the inhabitants of Belarus by neutron activation analysis using the k0-method. J Radioanal Nucl Chem. 1997;222(12):11-14.

63. Boulyga SF, Becker JS, Malenchenko AF, et al. Application of ICP-MS for multielement analysis in small sample amounts of pathological thyroid tissue. Microchim Acta. 2000;134(3-4):215-222.

64. Zakutinsky DK, Parfyenov Yu D, Selivanova LN. Handbook of the toxicology of radioactive isotopes. State Publishing House of Medical Literature, Moscow. 1962.

65. Kvicala J, Havelka J, Nemec J, et al. Selenium and rubidium changes in subjects with pathologically altered thyroid. Biol Trace Elem Res. 1992; $32: 253-258$

66. Kortev AI, Donthov GI, Lyascheva AP. Bioelements and a human pathology. Middle-Ural publishing-house, Sverdlovsk, Russia. 1972.

67. Katoh Y, Sato T, Yamamoto Y. Determination of multielement concentrations in normal human organs from the Japanese. Biol Trace Elem Res. 2002;90(1-3):57-70.

68. Schroeder HA, Tipton IH, Nason AP. Trace metals in man: strontium and barium. J Chron Dis. 1972;25(9):491-517.

69. Zaichick V. Sampling, sample storage and preparation of biomaterials for INAA in clinical medicine, occupational and environmental health. In: Harmonization of Health-Related Environmental Measurements Using Nuclear and Isotopic Techniques. IAEA, Vienna. 1997;123-133.

70. Zaichick V. Losses of chemical elements in biological samples under the dry aching process. Trace Elements in Medicine. 2004;5(3):17-22. 